\title{
A Critical View of Current State of Phytotechnologies to Remediate Soils: Still a Promising Tool?
}

\author{
Héctor M. Conesa, ${ }^{1}$ Michael W. H. Evangelou, ${ }^{2}$ Brett H. Robinson, ${ }^{3}$ and Rainer Schulin ${ }^{2}$ \\ ${ }^{1}$ Departamento de Ciencia y Tecnología Agraria, Universidad Politécnica de Cartagena, Paseo Alfonso XIII, \\ 48-30203 Cartagena, Spain \\ ${ }^{2}$ Institute of Terrestrial Ecosystems, Swiss Federal Institute of Technology (ETH Zürich), Universitaestrasse 16, \\ 8092 Zürich, Switzerland \\ ${ }^{3}$ Agriculture and Life Sciences, Lincoln University, Lincoln, Canterbury 7647, New Zealand
}

Correspondence should be addressed to Héctor M. Conesa, hector.conesa@upct.es

Received 7 October 2011; Accepted 2 November 2011

Academic Editors: R. Clemente and J. Ruelas-Inzunza

Copyright (C) 2012 Héctor M. Conesa et al. This is an open access article distributed under the Creative Commons Attribution License, which permits unrestricted use, distribution, and reproduction in any medium, provided the original work is properly cited.

\begin{abstract}
Phytotechnologies are often shown as an emerging tool to remediate contaminated soils. Research in this field has resulted in many important findings relating to plant and soil sciences. However, there have been scant private and public investments and little commercial success with this technology. Here, we investigate the barriers to the adoption of phytotechnologies and determine whether it is still a fertile area for future research. The terminology used in phytotechnologies includes a confusing mish-mash of terms relating to concepts and processes increasing the difficulty of developing a unique commercial image. We argue that the commercial success of phytotechnologies depends on the generation of valuable biomass on contaminated land, rather than a pure remediation technique that may not compare favourably with the costs of inaction or alternative technologies. Valuable biomass includes timber, bioenergy, feedstock for pyrolosis, biofortified products, or ecologically important species.
\end{abstract}

\section{Introduction}

Soil contamination has become an important environmental problem worldwide because of its detrimental effects on human and ecosystem health, soil productivity, and socioeconomic well-being. In 1994, there were an estimated 22 million ha of contaminated soils worldwide [1]. The European Environment Agency has estimated the total costs for the clean up of contaminated sites in Europe to be between EUR 59 and 109 billion [2]. Soil remediation projects need to incorporate environmental, technical, legislative, and economic factors, all of which are site specific.

Environmental regulations often obligate the remediation of soil if threshold values are exceeded [3-5] or there is an unacceptable risk to agricultural production, ecosystems, or human health [6]. Such regulation has placed an economic imperative to develop low-cost remediation technologies for contaminated soils.
Soil remediation techniques comprise in situ (non excavated soil) and ex situ techniques (soil is excavated). Ex situ remediation can be achieved on site, which requires the presence of a mobile decontamination unit, or off site, which requires that the soil be transported to a treatment facility (e.g., soil washing). Regulators tend to favour on-site techniques, which imply soil disposal as close to the source of contamination as possible $[5,7]$. The idea of "soil recycling" instead of disposal has been included in official regulations such as the directive 2008/1/EC concerning integrated pollution prevention and control [8]. Moreover, European Union regulators proposed within the same Directive a guideline to select the most suitable technique according to criteria such as environmental friendliness, preexisting scientific knowledge, or required time. Such guidelines leave stakeholders to choose the best remediation technology for their site, considering the economic, environmental, and social variables. 


\section{Biological and Nonbiological Methods}

Phytotechnologies have been defined as "the application of science and engineering to study problems and provide solutions involving plants" [9] or as "a set of technologies using plants to remediate or contain contaminants in soil, groundwater, surface water, or sediments" [10].

The costs of conventional methods to remediate soils (Table 1) are comparatively easy to estimate. They are usually based on known production and disposal rates, which permits an accurate estimate of the time required for remediation. However, these conventional engineering techniques can be prohibitively expensive (Table 1 ). These techniques generally have drawbacks such as generating high amounts of additional wastes that require disposal and are not suited for the treatment of soils that are to be reused for agricultural or similar purposes of plant/biomass production. For example, thermal treatments drastically alter the soil's biological and physical properties, which are the base of soil fertility. Similarly, soil-washing plants produce a residual clay-cake that has to be disposed of in a landfill.

To overcome these problems and to meet regulatory guidelines, scientific research in the last two decades studied in situ biological techniques which are environmental friendly as well as cost-effective. Among these techniques, phytotechnologies have received a particular high level of interest from the scientific community.

Phytotechnologies (or phytoremediation) include the removal of pollutants (phytoextraction) [11], their extraction from aqueous solution (e.g., rhizofiltration) [12], transformation (e.g., phytovolatilization) [13], or immobilization (e.g., phytostabilization) [14]. These techniques are frequently shown as promising tools for the remediation of contaminated sites. However, the successful application of these aforementioned technologies in commercial operations or field trials is scarce.

There are many scientific reviews of various aspects of phytotechnology [14-18]. Here, we discuss constraints and opportunities of phytotechnologies in the current environmental market, with a view to elucidating bottlenecks that hinder the commercial uptake of these technologies. We focus on the need to better transfer phytotechnologies to the commercial sector and explore ways to improve the economic viability of these technologies.

\section{The Need of a Conceptual Normalization}

Standardization is a key factor in the development of commercial products and services. For instance, there are standards for the investigation of soil, air, and water contamination under ISO 17020: 2004 (General criteria for the operation of various types of bodies performing inspection) (http://www .iso.org/). Soil remediation does not yet have a standard norm. However, increasing stakeholder demand and commercial needs could bring this about. Conventional remediation techniques, such as soil washing, thermal desorption, soil stabilization plants, would be easier to normalize than phytotechnologies, since yields and physicochemical processes are easier to predict and control than biological parameters, where complex physiological processes and ecological relationships play an overriding role. Therefore, it is imperative that phytotechnologies develop a distinctive image or brand in relation to commercial and environmental issues.

The number of concepts/processes in phytotechnologies has recently increased with the development of new research domains, and consequently new terms have been introduced to describe new techniques and findings in addition to the renaming of existing techniques (Figure 1). The high number of scientific terms for various processes, mechanisms, or techniques may lead to confusion in the marketplace. The nuances among concepts are often narrow. Non-specialized professionals may have difficulties to elucidate the most suitable technique for a given environmental issue. A review of the common terms that have been used in the last two decades in relation to phytotechnologies shows the lack of normalization among researchers. This is a natural consequence of the scientific progress. However, this confusion may hinder commercial acceptance. In particular, there is a common but wrong belief in the remediation market, as well as among some scientists, that phytotechnologies and in particular phytoremediation is synonymous with phytoextraction, a technology with limited potential application [19]. A comprehensive view of all the terms in use is even difficult for scientists. This can be seen in relation to rhizodegradation, defined as the use of rhizosphere processes involving microorganisms to remediate soils with organic pollutants [20]. That process has also been referred to as phytostimulation, enhanced rhizosphere degradation [20], rhizosphere bioremediation [21], plant-assisted bioremediation, or plant-aided in situ biodegradation [22].

In other cases, some terms promote confusion in relation to the mechanisms and biological processes that are involved: phytoimmobilization as it was described by Kaplan et al. [23] included two steps: first, metal phytoextraction and then, sequestration in top soil after leaf fall. Phytostabilization as defined by USEPA [22] refers to the contaminant immobilization in soil by accumulation/adsorption onto roots or precipitation within the rhizosphere, without previous translocation into leaves. The term, phytoextraction, introduced recently by Manousaki et al. [24], refers to the recovery of metals from plants that have the ability to excrete them. This implies phytoextraction, followed by excretion, and then deposition onto top soil, from where they must be removed. When phytostabilization is performed with the goal of returning contaminated land to its former natural state using native plants, the term phytorestoration [25] seems more adequate. Recently, phytoexclusion has been defined as a new technique within phytostabilization [17] to describe the use of excluders, that is, plants that have low bioaccumulation coefficients (shoot/soil metal concentration quotients). Although scientifically justified, the distinction between phytostabilization, phytorestoration, and phytoexclusion is unlikely to be made in the remediation market. Similarly, phytoremoval [26] could be considered as a synonym for phytoextraction. Phytopolishing [27] or plant-assisted remediation [28] are just other forms for phytoremediation. 
TABLE 1: Current prices and yields from conventional soil remediation techniques in Europe (prices from 2008 to 2009 , own data).

\begin{tabular}{lccccc}
\hline & Soil desorption & Soil washing & Soil stabilisation & Soil oxidation & Dig and dump \\
\hline Cost $($ euro/t) & $40-100$ & $25-40$ & $40-50$ & $60-70$ & $60-90$ \\
Yield $(\mathrm{t} / \mathrm{h})$ & $25-50$ & $35-80$ & $\sim 20$ & $\sim 50$ & - \\
\hline
\end{tabular}
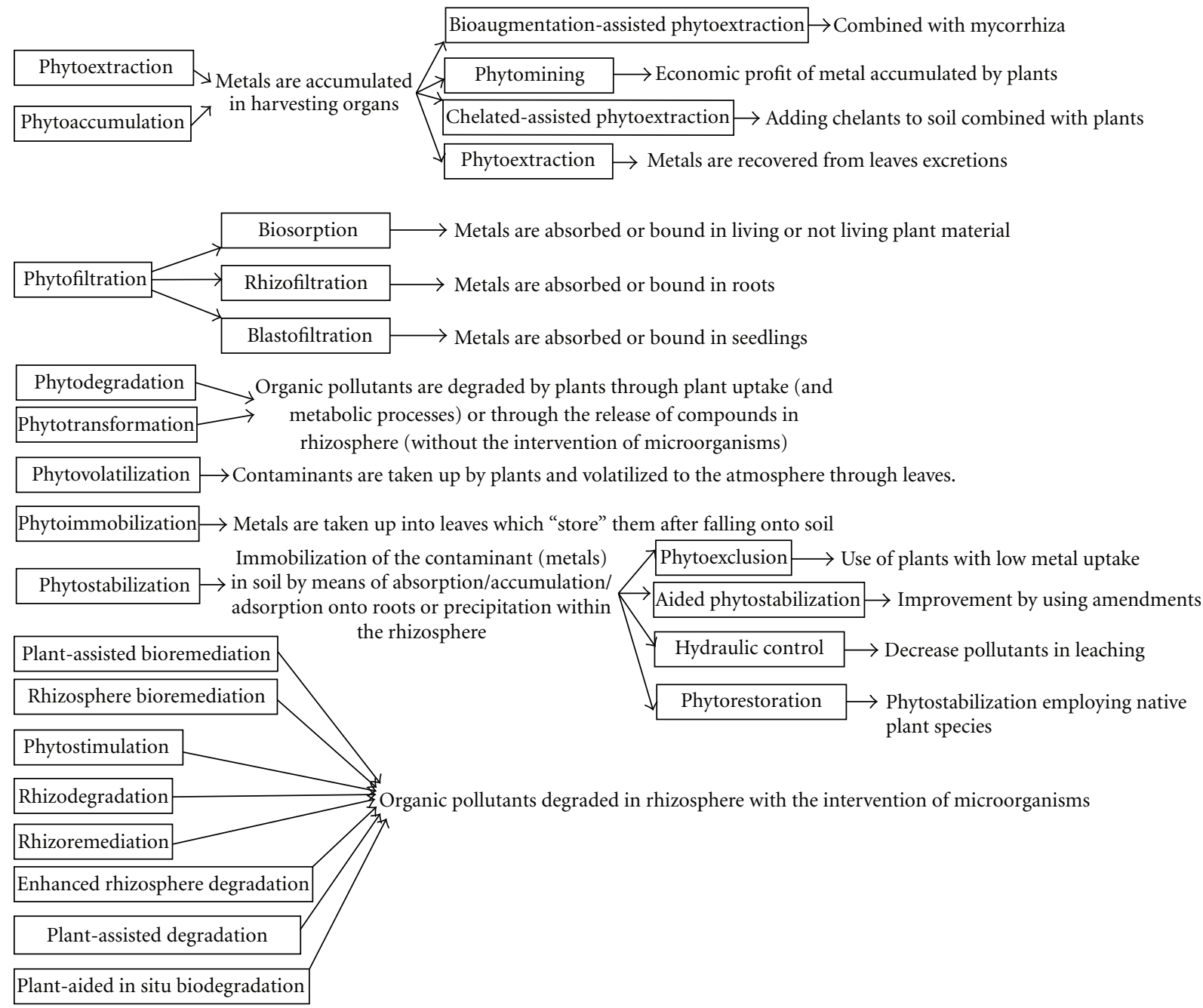

FIGURE 1: Current classification of most frequently used phytotechnologies for soil remediation.

For Alkorta et al. [20], phytofiltration included rhizofiltration (use of roots) and blastofiltration (the use of seedlings) to adsorb metals from water. Arthur et al. [16] referred to phytofiltration as the use of plant material (living and not living) to recover metals, and to rhizofiltration when roots were employed. Gardea-Torresdey et al. [29] employed the term phytofiltration when referring to the use of plantderived materials for removing heavy metals from aqueous media.

Phytodegradation [30], which is also called phytotransformation [22], was applied for organic compounds that are degraded, either within the plants or through compounds such as enzymes released into the rhizosphere but without the intervention of microorganisms. Rhizodegradation describes the same process involving microorganisms. If in a second step, the contaminants (organic and elemental such as As, $\mathrm{Hg}$, Se, etc.) are volatilized, then we talk about phytovolatilization.

Phytomanagement [31] describes the engineering or manipulation of soil-plant systems to control pollutant fluxes in the environment. Thus, the goal of phytomanagement may be simultaneously to alleviate deficiencies in essential trace elements such as $\mathrm{Zn}$ in produced crops and to reduce environmental risks posed by elevated concentrations of these elements in the soil. A key component of phytomanagement is that it should either cost less than other remediation technologies, or be a profitable operation, by producing valuable plant biomass products. Phytomanagement expresses the aggregation of complex phytoremediation techniques without distinguishing among involved processes. 


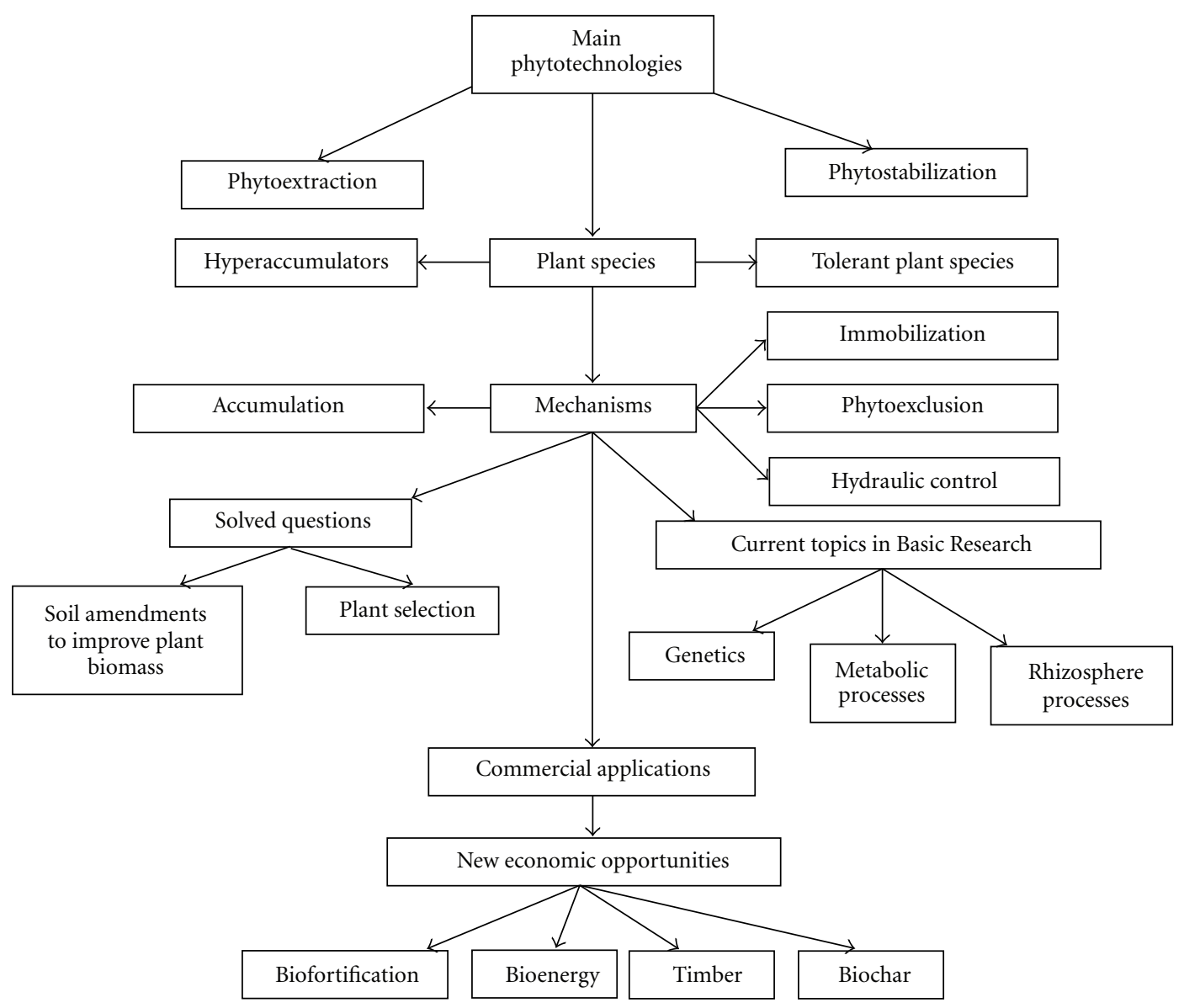

FIgure 2: Phytostabilization and phytoextraction application. Current and future development.

The commercial success of phytotechnologies requires the distinction of scientific and commercial goals, namely, between processes and techniques. The explosion of new terms may bring an additional problem for the commercial development of phytotechnologies because it may confuse nonspecialized stakeholders who are not familiar with these fields. There is an imperative for researchers to clarify these concepts. Two points are essential: the need of a conceptual redefinition and the elucidation of the most attractive commercial nomenclature. We discuss these issues below.

\section{Phytotechnologies Must Include Economics: The Need of a Conceptual Change}

The first articles detailing phytotechnologies emphasised the low costs of this emerging technology. After more than two decades of scientific development in this topic, recent reviews [18] still consider phytotechnologies as an emerging tool, showing that the reliability of phytoremediation, even inside the scientific community, has not yet been achieved. Thus, it is unsurprising that nonscientific stakeholders in contaminated sites are sceptical about its current applicability or future prospects. Initial estimates of the phytoremediation market by Glass [32] considered it to have a market potential worldwide of 34-54 billion US dollars. Virtually none of this potential has been materialized in the subsequent decade.

Current fundamental research in phytotechnologies (Figure 2) centres on two fields: (1) genetics/physiology/biochemistry in order to increasing plants' tolerance and metabolism of organic pollutants and/or trace elements [33] and (2) rhizosphere processes that influence the phytoavailability of pollutants [28]. Although these topics provide insights into scientific questions, the problem of phytotechnologies low commercial attractiveness due to its lack of revenues still remains. To overcome this issue, it has been proposed to use phytotechnology projects as a way of obtaining profitable outputs (Figure 2)

The original concept of phytoremediation focused on phytoextraction, while phytostabilization received much less attention [13]. The initial focus of phytotechnology was to remove pollutants from soils, by degradation and volatilization in case of organics and extraction in case of metals. Suitable phytoextraction projects relied on high metal extraction rates by the plant species used for remediation [34]. Thus, the research focused on the search for hyperaccumulator plant species [35] or using biotechnology (study of metabolic mechanisms, genetic engineering) to increase metal uptake $[15,36]$. This development has resulted in many important findings in plant science that relate to plant-pollutant 
interactions $[37,38]$ and to the selection of plant species with hyperaccumulation characteristics [39].

For some common metals, such as $\mathrm{Pb}$, there are no reliable reports of any hyperaccumulator species; therefore, chelant-assisted phytoextraction offered a possible solution. In chelant-assisted phytoextraction, various aminopolycarboxylic acids have been applied to soil to enhance the solubility of trace element cations $[40,41]$. Although plant uptake is increased, chelant-assisted phytoextraction has been comprehensively discredited [42, 43], because of the high leaching: plant uptake ratio of the contaminants and the persistence of chelants in the environment.

Successful phytoextraction requires the cleansing of the soil to a level that complies with environmental regulations. Field trials or commercial operations that demonstrate successful phytoextraction are conspicuously absent. Selenium volatilization using genetically engineered Brassica juncea (L.) is one of the few examples of a successful field application of phytoextraction [44]. Theoretically, repeated cropping of plants could cleanse contaminated sites, provided the harvested amounts of metals exceed further inputs, until the soil metals concentrations in the long term reach acceptable levels [31].

The development of phytoextraction brought additional issues of practicability, such as the further treatment of biomass, accumulation of pollutants in food chain, or the social and institutional acceptability of using of transgenic plants [45], which were ignored for decades. Back-of-the-envelope calculations show that phytoextraction is not suitable to remediate soils with moderate or high heavy metal contents since it would take an unacceptable time to remove those $[31,46]$. Such calculations, for example, rule out the use of phytoextraction in former mining areas. Moreover, there are concerns regarding the entry of metals into the food chain [47]. There has been a progressive shift away from phytoextraction towards phytostabilization. Most plants growing on metalliferous soils are not hyperaccumulators, but excluders of heavy metals. The use of excluders is the base of phytostabilization (Figure 2). Excluder plants may also transform metals into less toxic or mobile forms without extracting them from soil [34] through absorption and accumulation by roots, adsorption onto roots, or precipitation within the rhizosphere [48]. Recent reviews and studies indicate that phytostabilization has more scope of application than phytoextraction [17].

The term phytotechnology relates to biochemical processes that can permanently modify an ecosystem. Plants affect evapotranspiration rates, mobilise, immobilise, or extract metals and other chemicals from soil, introduce organic matter into soil, and also release a variety of chemicals by exudation [19]. The original categorization of a project as phytostabilization or phytoextraction may change as the project progresses. Recently, Robinson et al. [31] and Domínguez et al. [49] have extended the phytoremediation concept to more applied projects, showing it as an integrative tool to manage restoration works at large scale using plants for hydraulic control and limitation of metal uptake. This new way of understanding phytotechnologies as phytomanagement is based on the use of the contaminated land for the production of economic yield [31]. Here, remediation is redefined within a dynamic system, which maintains the risks of the contaminants at a safe level and where the factor "soil" generates an economic gain (energy crops, pasture, biofortified products, etc.). That means that phytotechnologies no longer have the sole goal of soil remediation but also of generating economic benefits, and this necessitates redirecting current research lines to more applied aspects.

4.1. Economic Evaluation. According to Lewandowski et al. [50], the quantification of land use functions in biophysical terms requires site-specific information on the landscape, site conditions, or plant species and the identification of target groups which may have benefits from phytotechnologies (farmers, authorities, industries, etc.). This implies that evaluation costs are site-specific and, therefore, that general economic assumptions or yield rates cannot be estimated without site-specific studies. As an initial step in the economic evaluation of phytomanagement projects, some scenarios have to be established in the decision-making process. Potential scenarios (Figure 3 ) in waste management according to the EC [7] are the following:

(i) a do-nothing scenario ("business as usual"), without investments,

(ii) some available alternatives inside the current proposal,

(iii) global alternatives to the project.

One of the main barriers for the application of phytotechnologies is the absence of economic studies or cost evaluations. Efforts have been recently made in studying at local or regional scales the economic profits of bioenergy production in contaminated lands $[51,52]$. The presentation of phytoremediation as novel low cost remediation technology may not be borne out if the time when the land is out of production is taken into consideration. In a real cost evaluation, "time consuming" is assumed to be an additional cost, and this makes the cost of phytoremediation uncertain because it is difficult to evaluate. Large remediation operations usually come in association with big projects (urban, commercial, industrial). Most commercial soil remediation occurs in relation to the growth of urban areas, where low levels of contaminations must be reached, change of soil use or toxic spills, where urgent solutions are needed to maintain sociopolitical acceptance. In these cases, conventional remediation options are often the best option due to their rapidity, despite their high initial cost. This makes it difficult for phytotechnologies to compete. Therefore, they are relegated to projects with low economic value and the following profile: (a) long term period is possible; (b) current use of soil does not imply risks for people/ecosystems. These kinds of projects are usually restricted to marginal areas without short term economic value, such as former mining areas $[47,53]$, landfills, abandoned shooting ranges [54], or postindustrial sites [55].

Lewandowski et al. [56] assessed economic value of phytoremediation combined with biomass production in a $\mathrm{Cd}$ polluted soil. According to these authors, assessing the economic value of that combined option requires the accounting 


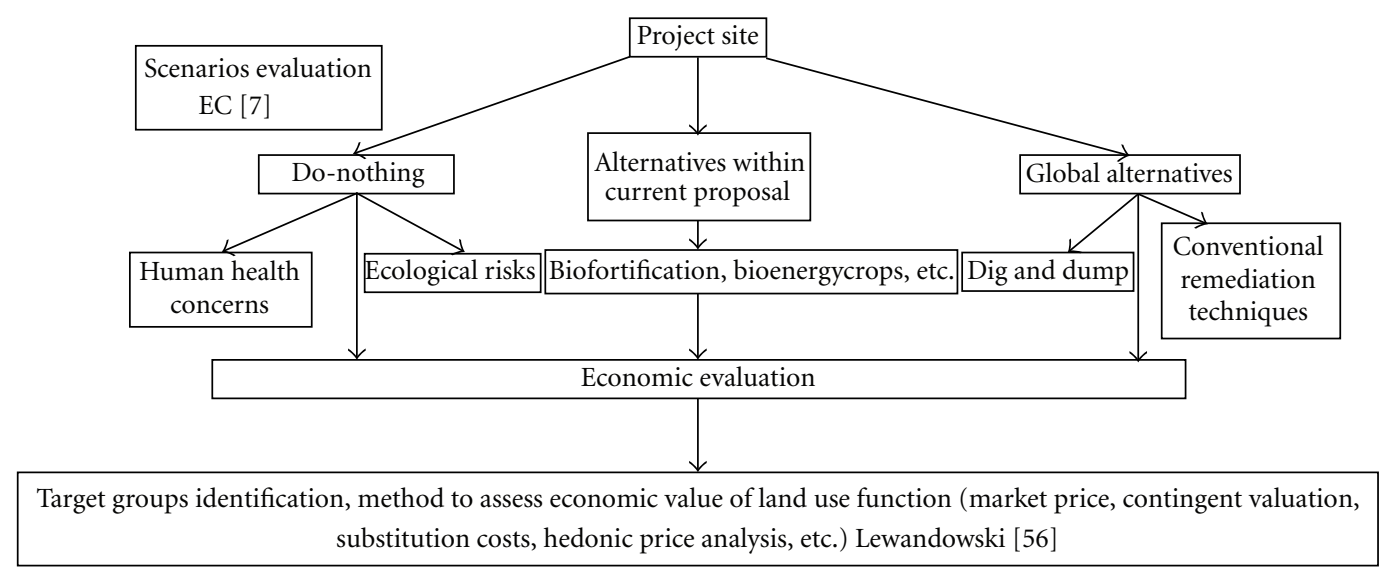

FIgURE 3: Scheme of evaluation steps in a project remediation site.

of market price of the biomass, contingent valuation/willingness-to-pay or substitution costs/replacement costs.

\subsection{Commercial Management. There are differences between} Europe and North America in the commercial management of phytotechnologies. North America has higher private investment in phytotechnologies, and this has resulted in a larger number of profitable private companies. In contrast, Europe is more focused on solving fundamental issues and in describing biological mechanisms [57]. Consequently, North America is far ahead of Europe in the application and commercialisation of phytotechnologies. Phytoremediation companies have undergone structural and conceptual development in the last 15 years. The first phytoremediation companies were regional manufacturers offering phytoextraction of radionuclides and trace elements (e.g., Phytotech Inc.), or the removal of organics from soil and groundwater by means of trees (e.g., Phytokinetics Inc.). Many of these companies went out of business, because there are few sites that can be remediated solely by phytoextraction. Nowadays, for fieldscale remediation, phytoremediation companies team up with large engineering firms, if the latter do not already have an integrated phytoremediation division. Some phytoremediation companies have abandoned the clean up business and practice phytomanagement: most phytotechnology projects aim to prevent contaminant leaching into groundwater (Ecolotree) and the treatment of effluent (Bioplanta). As phytoremediation is a field that is highly dependent on the economic climate, some companies such as Bioplanta Inc. have found additional sources of income, such as methane production in bioreactors or the extraction of active compounds from plants to boost profits. Although some companies have made profits from the field of phytoremediation, the actual breakthrough of this technique has yet not been made. The reason could be that in contrast to other environmental technologies such as renewable energy production by solar panels, wind turbines, and so forth, this technique does not produce profitable outputs. The use of contaminated land for the production of energy crops could reduce the importance of cleanup times while producing a revenue stream [51]. Moreover, "pure environmental" benefits (e.g., $\mathrm{CO}_{2}$ friendly, increase of biodiversity) must be considered and, therefore, incorporated to the economic evaluation.

4.3. Emerging Opportunities. Biofortification aims to increase the concentration of essential trace elements in crops to improve human health and agricultural productivity [58]. Micronutrients such as Fe and $\mathrm{Zn}$ are deficient in many diets [59]. Physiologically accumulated micronutrients in plants provide a more readily assimilable source of micronutrients than in the form of inorganic supplements [58]. Some field experiments have shown positive results in relation to Se-fortified vegetables [60]. According to Qaim et al. [61], biofortification is likely to gain in importance in the future, as indicated by the large number of related international research programs recently launched. However, more evidence, including medical trials, toxicity assessment, and appropriate dosages is needed before biofortified products be available for the consumers $[62,63]$.

Phytotechnologies may increase revenues from nonproductive polluted soils if linked with biomass production $[56,64]$. Among the different options, the production of biofuels, nonconsumable agricultural products, or wood is economically viable in many countries. Biofuels are highly depended on subsidies, and they will establish themselves commercially only when the oil price exceeds 120 US \$ per barrel [65]. In contrast to biofuel production, production of biochar could give a new perspective on the production of biomass on contaminated land. Biochar is charcoal created from the pyrolysis of biomass. The addition of biochar to soil has been suggested as a means to sequester carbon, thereby reducing the effects of human-induced climate change caused by $\mathrm{CO}_{2}$ emissions [66].

The economics of biochar will depend on the plant species used and the farming intensity applied (fertilisers, pesticides, herbicides) as this will affect operational costs. Monocultures are vulnerable under inadequate soils or stress conditions (drought, pathogens) making it an important issue to reach sustainable system to guarantee the economic and 


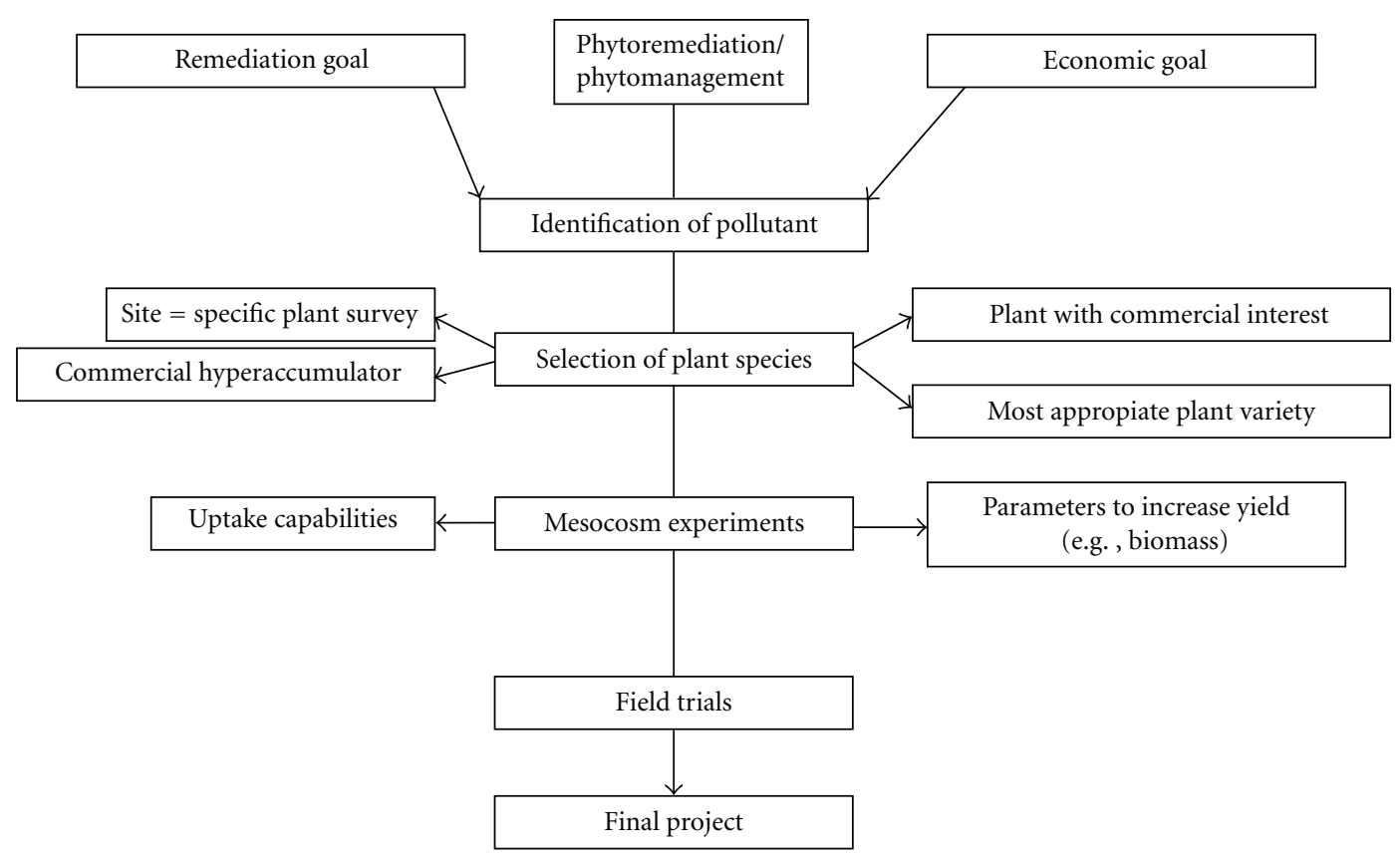

FIgure 4: Phytoremediation decision tree.

ecological stability of the local environment [67]. Therefore, crops are best when rotated or, if possible, a multispecies community must be established. Additionally, the use of food producing from agricultural species such as maize, rape, and sunflower contains the risk that the contaminants contained in the harvest may enter food or fodder, thus posing a risk to humans and animals. In addition to agricultural species, tree plantation could be an option, with rotation periods of up to 25 years [68]. This rotation would be similar to rotation periods of forestry and would have reduced expenses compared to short-term rotations because of lower plantation costs. This implementation, however, would make it unsuitable for short-term financial outputs. Since the land is anyway not producing revenue and the trees have phytostabilising potential, short rotation periods are less important.

Another possibility may be phytomining; the use of plants to mine metals [69] has been shown to be economically feasible for certain metals such as nickel $[70,71]$. However, practical aspects, especially efficiency of land use will prohibit its widespread use [31]. Greater efforts in developing rates, modelling, treatment times, and monitoring schemes are still necessary to provide a better practical view of this technology [30, 72].

4.4. Adoption of a New Concept. Traditionally, phytotechnology projects had the sole aim of remediating the site. There is a lot of information on candidate plant species for these technologies, especially regarding plant metal-accumulation and tolerance $[46,73]$. Mesocosm experiments have been employed to reveal the capabilities and limitations of soil conditioners [74]. The results of some successful field trials in specific sites are also available $[31,44]$.
Unlike other remediation systems such as capping and soil removal, phytotechnologies systems are site dependent. It is impractical to conduct long-term field trials to optimise phytotechnology systems for each site. Therefore, models that calculate the performance of phytotechnology systems are crucial. Such models could eliminate unnecessary field trials by revealing where phytotechnologies will likely meet environmental regulations and where they are more costeffective than competing technologies. Without such models, the improvement of phytotechnologies requires field trials to determine the feasibility and optimal management strategies for the site. This further delays the operation.

Approaching phytotechnologies from a commercial perspective, such as has occurred in the United States, is more likely to increase the attractiveness of this technology. Figure 4 shows the current implementation pathway for phytotechnologies using this system. The critical success factor for this system is that the remediation goal and the economic goal are given equal weightings.

\section{Conclusions}

Research in phytotechnologies has enhanced our understanding in the fields of plant and soil sciences. However, more effective and commercially feasible techniques are still required. Therefore, to make phytotechnologies more commercially attractive, we propose:

(i) clearly distinguishing processes from techniques to improve communication and cooperation by the commercial sector,

(ii) the exploitation of new economic opportunities such as the production bioenergy, biochar, and biofortified crops, 
(iii) the application of economic studies and economic evaluations as well as a new implementation protocol. Phytotechnologies will forever remain a promising tool for soil cleaning if they are not linked to the production of valuable biomass products.

\section{Acknowledgments}

Dr. Héctor M. Conesa thanks the Spanish Ministerio de Ciencia e Innovacion and UPCT for funding through the "Ramon y Cajal" programme (Ref. RYC-2010-05665). Michael W. H. Evangelou would like to thank the DFG (German Research Foundation) for funding his research fellowship.

\section{References}

[1] GACGC (German Advisory Council on Global Change), World in Transition: The Threat to Soils, Economica Verlag GmbH, Bonn, Germany, 1994.

[2] CEC (Commission of the European Communities), Communication from the Commission to the Council, the European Parliament, the Economic and Social Committee and the Committee of the Regions: Towards a Thematic Strategy for Soil Protection, $\operatorname{COM}(2002) 179$ final, European Commision, Brussels, Belgium, 2002.

[3] S. Bundesrat, 814.12 Verordnung vom 1. Juli 1998 über Belastungen des Bodens (VBBo), Switzerland, 1998.

[4] MHSPE (Ministry of Housing, Spatial Planning and Environment), Netherlands: Circular on Target Values and Intervention Values for Soil Remediation, Ministry of Housing, Spatial Planning and Environment, Amsterdam, The Netherlands, 2000.

[5] BOE (Boletín Oficial del Estado), "Real Decreto 9/2005, de 14 de enero, por el que se establece la relación de actividades potencialmente contaminantes del suelo y los criterios y estándares para la declaración de suelos contaminados," (BOE no. 15 de 18.01.05), pp. 1833-1843, 2005. Spain. (in Spanish).

[6] F. A. Swartjes, "Risk-based assessment of soil and groundwater quality in The Netherlands: standards and remediation urgency," Risk Analysis, vol. 19, no. 6, pp. 1235-1249, 1999.

[7] EC (European Comission), Guide to Cost-Benetfit Analysis of Investment Projects: Evaluation Unit DG Regional Policy European Commission, Structural Fund-ERDF, Cohesion Fund and ISPA, 2002.

[8] EU (European Union), "Directive 2008/1/EC of the European Parlament and of the Council of 15 January 2008 concerning integrated pollution prevention and control," (29-01-2008), 2008.

[9] UNEP (United Nations Environment Programme), "Freshwater management series no. 7 phytotechnologies: a technical approach in environmental management," 2003, http://www .unep.or.jp/ietc/publications/freshwater/fms7/index.asp.

[10] ITRC (Interstate Technology and Regulatory Cooperation), "Phytotechnology technical and regulatory guidance and decision trees, Revised Technical/Regulatory Guidance Interstate Technology \& Regulatory Council Phytotechnologies," U.S. 2009, http://www.itrcweb.org/Documents/PHYTO-3.pdf.

[11] I. Raskin, "Phytoextraction: the use of plants to remove heavy metals from soils," Environmental Science and Technology, vol. 29, no. 5, pp. 1232-1238, 1995.
[12] V. Dushenkov, P. B. A. Nanda-Kumar, H. Motto, and I. Raskin, "Rhizofiltration: the use of planst to remove havy metals from aqueous streams," Environmental Science and Technology, vol. 29, pp. 1239-1245, 1995.

[13] I. Raskin, R. D. Smith, and D. E. Salt, "Phytoremediation of metals: using plants to remove pollutants from the environment," Current Opinion in Biotechnology, vol. 8, no. 2, pp. 221226, 1997.

[14] D. E. Salt, M. Blaylock, N. P. B. A. Kumar et al., "Phytoremediation: a novel strategy for the removal of toxic metals from the environment using plants," Bio-technology, vol. 13, no. 5, pp. 468-474, 1995.

[15] U. Krämer, "Phytoremediation: novel approaches to cleaning up polluted soils," Current Opinion in Biotechnology, vol. 16, no. 2, pp. 133-141, 2005.

[16] E. L. Arthur, P. J. Rice, P. J. Rice et al., "Phytoremediation-an overview," Critical Reviews in Plant Sciences, vol. 24, no. 2, pp. 109-122, 2005.

[17] N. M. Dickinson, A. J. M. Baker, A. Doronila, S. Laidlaw, and R. D. Reeves, "Phytoremediation of inorganics: realism and synergies," International Journal of Phytoremediation, vol. 11, no. 2, pp. 97-114, 2009.

[18] A. P. G. C. Marques, A. O. S. S. Rangel, and P. M. L. Castro, "Remediation of heavy metal contaminated soils: phytoremediation as a potentially promising clean-up technology," Critical Reviews in Environmental Science and Technology, vol. 39, no. 8, pp. 622-654, 2009.

[19] B. Robinson, R. Schulin, B. Nowack et al., "Phytoremediation for the management of metal flux in contaminated sites," Forest Snow and Landscape Research, vol. 80, no. 2, pp. 221224, 2006.

[20] I. Alkorta, J. Hernández-Allica, J. M. Becerril, I. Amezaga, I. Albizu, and C. Garbisu, "Recent findings on the phytoremedation of soils contaminated with environmentally toxic heavy metals and metalloids such as zinc, cadmium, lead, and arsenic," Reviews in Environmental Science and BioTechnology, vol. 3, pp. 71-90, 2004.

[21] J. L. Schnoor, "Phytoremediation of soil and groundwater," Technology Evaluation Report TE-02-01, Ground Water Remediation Technologies Analysis Center (GWRTAC), Pittsburgh, Pa, USA, 2002.

[22] USEPA (United States Environmental Protection Agency), Introduction to Phytoremediation, EPA/600/R-99/107, Boston, Mass, USA, 2000.

[23] D. I. Kaplan, A. S. Knox, T. G. Hinton, R. R. Sharitz, B. P. Allen, and S. M. Serkiz, "Proof-of-concept of the phytoimmobilization technology for TNX outfall delta," Final Report, Westinghouse Savannah River Company, Aiken, SC, USA, 2001.

[24] E. Manousaki, J. Kadukova, and N. Kalogerakis, "Phytoextraction and phytoexcretion of $\mathrm{Cd}$ and $\mathrm{Pb}$ by the salt cedar (Tamarix Smyrensis Bunge): a new combined phytoremediation process," COST Action 859-Phytotechnologies in practice-biomass production, agricultural methods, legacy, legal and economic aspects October 14-17, Verneuil-enHalatte, France, 2008.

[25] W. A. Peer, I. R. Baxter, E. L. Richards, J. L. Freeman, and A. S. Murphy, "Phytoremediation and hyperaccumulator plants," Topics in Current Genetics, pp. 299-340, 2006.

[26] V. Campos and M. A. F. Pires, "Phytoremoval of arsenic from soil," Communications in Soil Science and Plant Analysis, vol. 358, no. 15-16, pp. 2137-2146, 2003.

[27] Z. D. Parris, M. K. Banks, A. P. Schwab, and J. C. White, "Phyto-polishing of land-treated manufactured gas plant 
(MGP) soil," Intertational Journal of Phytoremediation, vol. 6, p. $188,2004$.

[28] W. W. Wenzel, "Rhizosphere processes and management in plant-assisted bioremediation (phytoremediation) of soils," Plant and Soil, vol. 321, no. 1-2, pp. 385-408, 2009.

[29] J. L. Gardea-Torresdey, G. De la Rosa, and J. R. Peralta-Videa, "Use of phytofiltration technologies in the removal of heavy metals: a review," Pure and Applied Chemistry, vol. 76, no. 4, pp. 801-813, 2004.

[30] L. A. Newman and C. M. Reynolds, "Phytodegradation of organic compounds," Current Opinion in Biotechnology, vol. 15, no. 3, pp. 225-230, 2004.

[31] B. H. Robinson, G. Bañuelos, H. M. Conesa, M. W. H. Evangelou, and R. Schulin, "The phytomanagement of trace elements in soil," Critical Reviews in Plant Sciences, vol. 28, no. 4, pp. 240-266, 2009.

[32] D. J. Glass, "US and international markets for phytoremediation,” Tech. Rep., D. Glass Associates, Needham, Mass, USA, 1999.

[33] D. N. Dowling and S. L. Doty, "Improving phytoremediation through biotechnology," Current Opinion in Biotechnology, vol. 20, no. 2, pp. 204-206, 2009.

[34] R. L. Chaney, M. Malik, Y. M. Li et al., "Phytoremediation of soil metals," Current Opinion in Biotechnology, vol. 8, no. 3, pp. 279-284, 1997.

[35] A. J. M. Baker, S. P. McGrath, C. M. D. Sidoli, and R. D. Reeves, "The possibility of in situ heavy metal decontamination of polluted soils using crops of metal-accumulating plants," Resources, Conservation and Recycling, vol. 11, no. 1-4, pp. 4149, 1994.

[36] S. P. McGrath and F. J. Zhao, "Phytoextraction of metals and metalloids from contaminated soils," Current Opinion in Biotechnology, vol. 14, no. 3, pp. 277-282, 2003.

[37] M. M. Lasat, "Phytoextraction of toxic metals: a review of biological mechanisms," Journal of Environmental Quality, vol. 31, no. 1, pp. 109-120, 2002.

[38] X. Yang, Y. Feng, Z. He, and P. J. Stoffella, "Molecular mechanisms of heavy metal hyperaccumulation and phytoremediation," Journal of Trace Elements in Medicine and Biology, vol. 18, no. 4, pp. 339-353, 2005.

[39] R. R. Brooks, Ed., Plants that Hyperaccumulate Heavy Metals, CAB International Publishing, Oxford University Press, 1998.

[40] J. W. Huang and S. D. Cunningham, "Lead phytoextraction: species variation in lead uptake and translocation," New Phytologist, vol. 134, no. 1, pp. 75-84, 1996.

[41] M. J. Blaylock, D. E. Salt, S. Dushenkov et al., "Enhanced accumulation of $\mathrm{Pb}$ in Indian mustard by soil-applied chelating agents," Environmental Science and Technology, vol. 31, no. 3, pp. 860-865, 1997.

[42] B. Nowack, R. Schulin, and B. H. Robinson, "Critical assessment of chelant-enhanced metal phytoextraction," Environmental Science and Technology, vol. 40, no. 17, pp. 5225-5232, 2006.

[43] M. W. H. Evangelou, M. Ebel, and A. Schaeffer, "Chelate assisted phytoextraction of heavy metals from soil: effect, mechanism, toxicity, and fate of chelating agents," Chemosphere, vol. 68, no. 6, pp. 989-1003, 2007.

[44] G. Bañuelos, N. Terry, D. L. Leduc, E. A. H. Pilon-Smits, and B. Mackey, "Field trial of transgenic Indian mustard plants shows enhanced phytoremediation of selenium-contaminated sediment," Environmental Science and Technology, vol. 39, no. 6, pp. 1771-1777, 2005.
[45] A. K. Wolfe and D. J. Bjornstad, "Why would anyone object? An exploration of social aspects of phytoremediation acceptability," Critical Reviews in Plant Sciences, vol. 21, no. 5, pp. 429-438, 2002.

[46] H. M. Conesa, A. Faz, and R. Arnaldos, "Heavy metal accumulation and tolerance in plants from mine tailings of the semiarid Cartagena-La Unión mining district (SE Spain)," Science of the Total Environment, vol. 36, no. 1, pp. 1-11, 2006.

[47] H. M. Conesa, A. Faz, and R. Arnaldos, "Initial studies for the phytostabilization of a mine tailing from the CartagenaLa Union Mining District (SE Spain)," Chemosphere, vol. 66, no. 1, pp. 38-44, 2007.

[48] M. H. Wong, "Ecological restoration of mine degraded soils, with emphasis on metal contaminated soils," Chemosphere, vol. 50, no. 6, pp. 775-780, 2003.

[49] M. T. Domínguez, T. Marañón, J. M. Murillo, R. Schulin, and B. H. Robinson, "Trace element accumulation in woody plants of the Guadiamar Valley, SW Spain: a large-scale phytomanagement case study," Environmental Pollution, vol. 152, no. 1, pp. 50-59, 2008.

[50] I. Lewandowski, M. Londo, U. Schmidt, and A. P. Faaij, "Biomass production in multiple land use systems: categorization of feasible land use functions and their Quantification by the example of phytoremediation," in Proceedings of the 2nd World Conference and Technology Exhibition on Biomass for Energy, Industry and Climate Protection, pp. 54-57, Rome, Italy, May 2004.

[51] N. Witters, S. van Slycken, A. Ruttens et al., "Short-rotation coppice of willow for phytoremediation of a metal-contaminated agricultural area: a sustainability assessment," Bioenergy Research, vol. 2, no. 3, pp. 144-152, 2009.

[52] E. Meers, S. van Slycken, K. Adriaensen et al., "The use of bio-energy crops (Zea mays) for 'phytoattenuation' of heavy metals on moderately contaminated soils: a field experiment," Chemosphere, vol. 78, no. 1, pp. 35-41, 2010.

[53] M. O. Mendez and R. M. Maier, "Phytoremediation of mine tailings in temperate and arid environments," Reviews in Environmental Science and Biotechnology, vol. 7, no. 1, pp. 4759, 2008.

[54] B. H. Robinson, S. Bischofberger, A. Stoll et al., "Plant uptake of trace elements on a Swiss military shooting range: uptake pathways and land management implications," Environmental Pollution, vol. 153, no. 3, pp. 668-676, 2008.

[55] C. J. French, N. M. Dickinson, and P. D. Putwain, "Woody biomass phytoremediation of contaminated brownfield land," Environmental Pollution, vol. 141, no. 3, pp. 387-395, 2006.

[56] I. Lewandowski, U. Schmidt, M. Londo, and A. Faaij, "The economic value of the phytoremediation function-assessed by the example of cadmium remediation by willow (Salix ssp)," Agricultural Systems, vol. 89, no. 1, pp. 68-89, 2006.

[57] N. Marmiroli, M. Marmiroli, and E. Maestri, "Phytoremediation and phytotechnologies: a review for the present and the future," in Viable Methods of Soil and Water Pollution Monitoring, Protection and Remediation, I. Twadowska, M. M. Haggblom, and S. Stefaniak, Eds., vol. 69, pp. 403-416, NATO Science Series IV Earth and Environmental Sciences, 2006.

[58] P. J. White and M. R. Broadley, "Biofortifying crops with essential mineral elements," Trends in Plant Science, vol. 10, no. 12, pp. 586-593, 2005.

[59] F. Branca and M. Ferrari, "Impact of micronutrient deficiencies on growth: the stunting syndrome," Annals of Nutrition and Metabolism, vol. 46, no. 1, pp. 8-17, 2002. 
[60] G. S. Bañuelos, "Phyto-products may be essential for sustainability and implementation of phytoremediation," Environmental Pollution, vol. 144, no. 1, pp. 19-23, 2006.

[61] M. Qaim, A. J. Stein, and J. V. Meenakshi, "Economics of biofortification,” Agricultural Economics, vol. 37, no. 1, pp. 119-133, 2007.

[62] D. N. Cox and K. Bastiaans, "Understanding Australian consumers' perceptions of selenium and motivations to consume selenium enriched foods," Food Quality and Preference, vol. 18, no. 1, pp. 66-76, 2007.

[63] F. J. Zhao and S. P. McGrath, "Biofortification and phytoremediation," Current Opinion in Plant Biology, vol. 12, no. 3, pp. 373-380, 2009.

[64] L. A. Licht and J. G. Isebrands, "Linking phytoremediated pollutant removal to biomass economic opportunities," Biomass and Bioenergy, vol. 28, no. 2, pp. 203-218, 2005.

[65] W. E. Tyner, "Policy update: cellulosic biofuels market uncertainties and government policy," Biofuels, vol. 1, pp. 389-391, 2010.

[66] J. Lehmann, "Bio-energy in the black," Frontiers in Ecology and the Environment, vol. 5, no. 7, pp. 381-387, 2007.

[67] P. Schröder, R. Herzig, B. Bojinov et al., "Bioenergy to save the world: producing novel energy plants for growth on abandoned land," Environmental Science and Pollution Research, vol. 15, no. 3, pp. 196-204, 2008.

[68] B. Klasnja, S. Kopitovic, and S. Orlovic, "Wood and bark of some poplar and willow clones as fuelwood," Biomass and Bioenergy, vol. 23, no. 6, pp. 427-432, 2002.

[69] R. R. Brooks, M. F. Chambers, L. J. Nicks, and B. H. Robinson, "Phytomining," Trends in Plant Science, vol. 3, no. 9, pp. 359362, 1998.

[70] R. L. Chaney, J. S. Angle, A. J. M. Baker, and Y.-M. Li, "Method for phytomining of nickel, cobalt, and other metals from soil," U.S. Patent, no. 5,711,784, 1998.

[71] Y. M. Li, R. Chaney, E. Brewer et al., "Development of a technology for commercial phytoextraction of nickel: economic and technical considerations," Plant and Soil, vol. 249, no. 1, pp. 107-115, 2003.

[72] L. van Nevel, J. Mertens, K. Oorts, and K. Verheyen, "Phytoextraction of metals from soils: how far from practice?" Environmental Pollution, vol. 150, no. 1, pp. 34-40, 2007.

[73] R. C. González and M. C.A. González-Chávez, "Metal accumulation in wild plants surrounding mining wastes," Environmental Pollution, vol. 144, no. 1, pp. 84-92, 2006.

[74] H. M. Conesa, B. H. Robinson, R. Schulin, and B. Nowack, "Growth of Lygeum spartum in acid mine tailings: response of plants developed from seedlings, rhizomes and at field conditions," Environmental Pollution, vol. 145, no. 3, pp. 700707, 2007. 

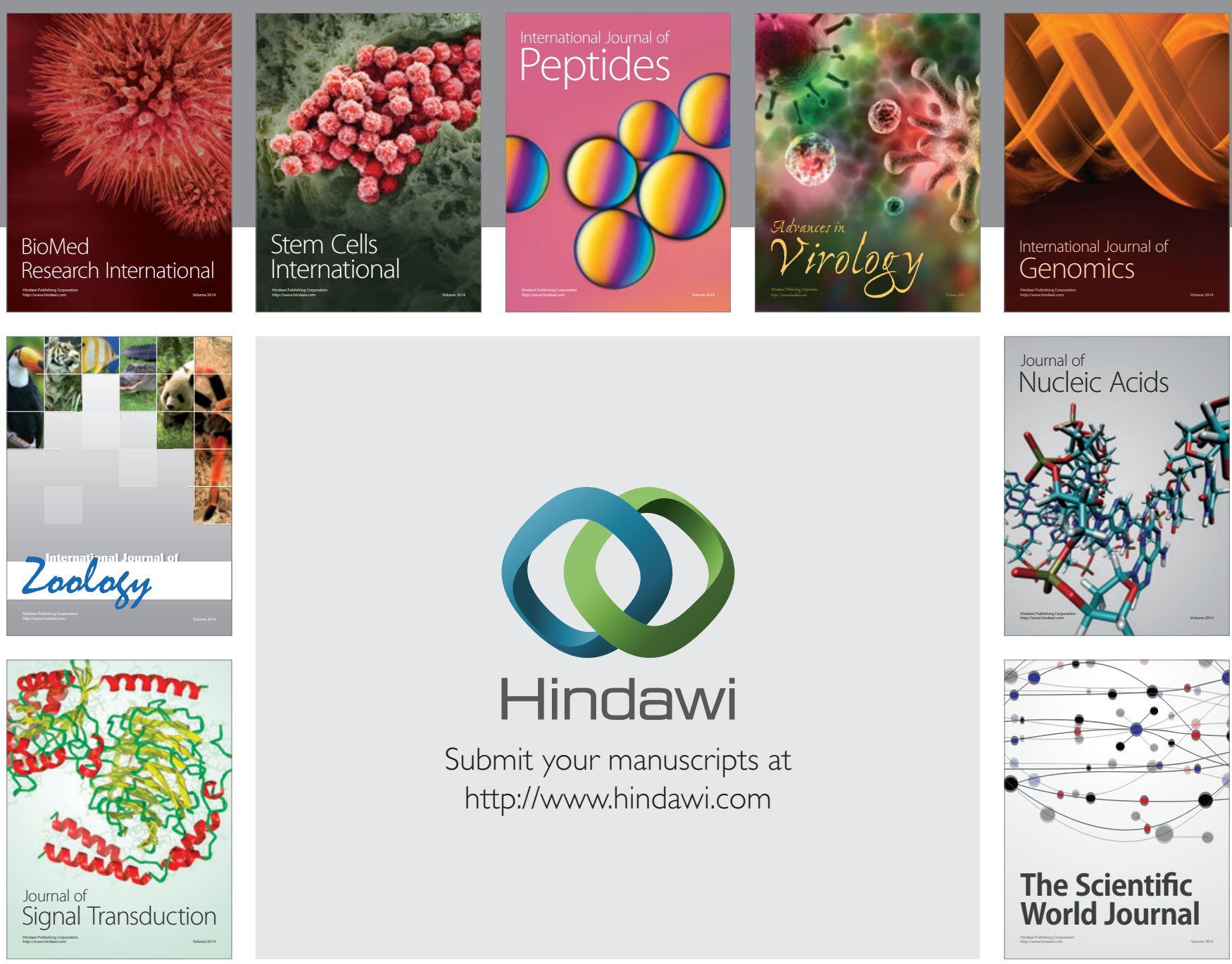

Submit your manuscripts at

http://www.hindawi.com
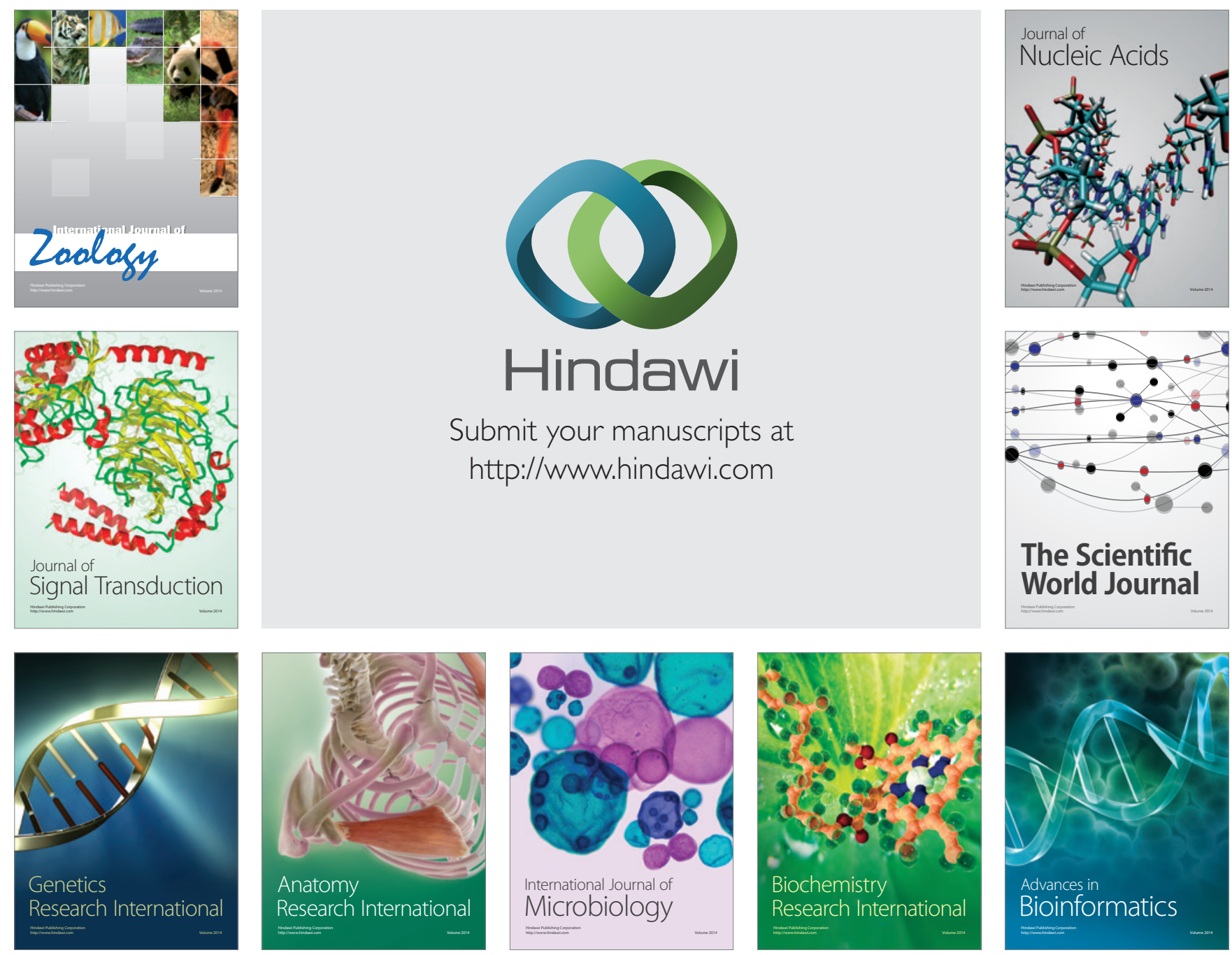

The Scientific World Journal
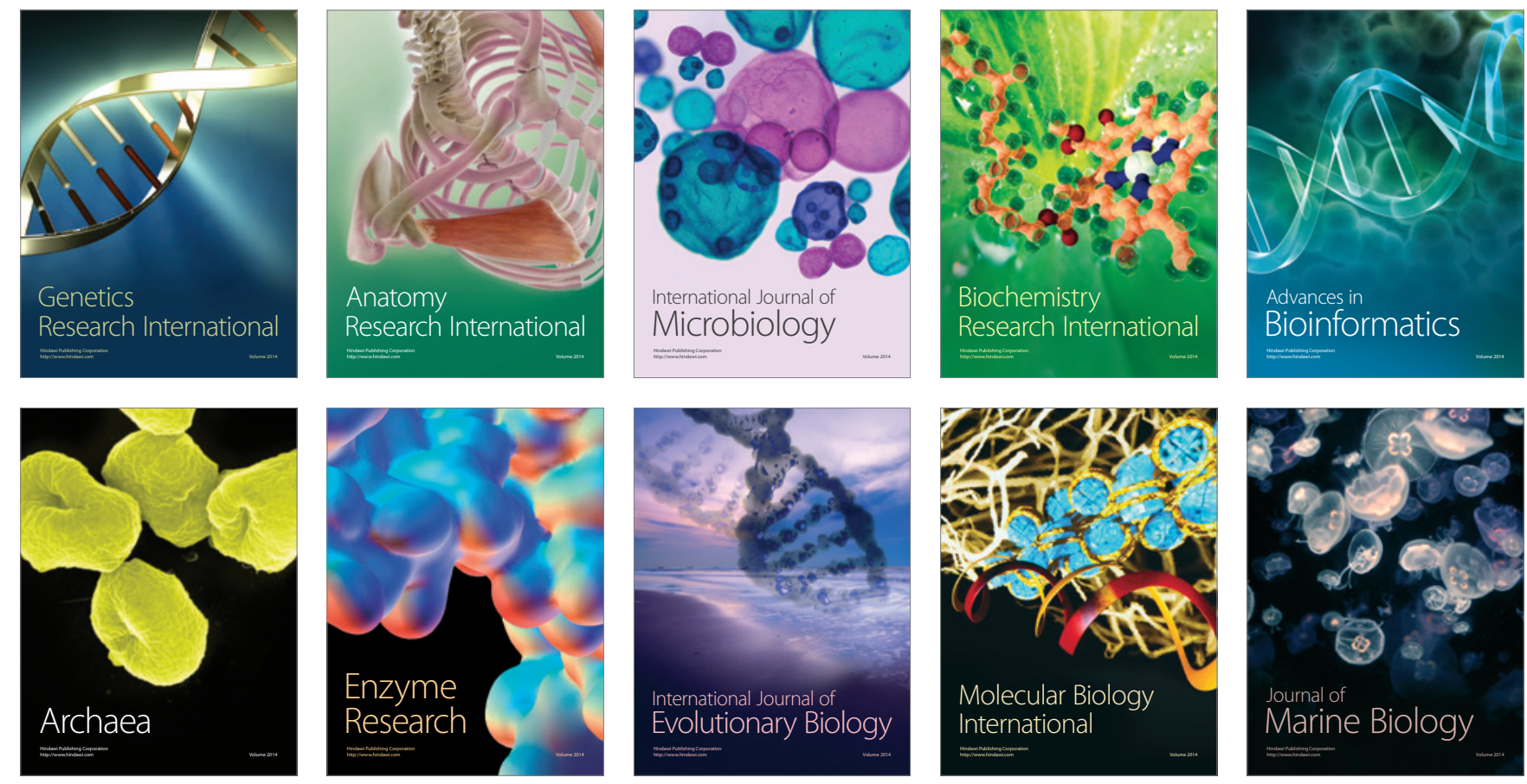